\title{
LEVEL OF SEASONALITY IN MACEDONIAN TOURISM AND STRATEGIES AND POLICIES FOR COPING WITH IT
}

\author{
Biljana Petrevska, PhD, Asociate Professor ${ }^{1}$ \\ Branko Nikolovski, PhD, Full Professor ${ }^{2}$
}

DOI: https://doi.org/10.31410/tmt.2018.17

\begin{abstract}
Seasonality is general characteristic of tourism. As tourism contributes to economic growth and development, seasonality is noted as one of the most influencing factors for limiting continuous development. Thus, the article empirically tests the presence of tourism seasonality for the central level by exploring Macedonia, and the local level, by elaborating Ohrid (the most famous summer tourist spot) and Skopje (the capital). The statistical methodology covers computation of standard indicators, such as the Gini index (G), the Seasonality Indicator (SI) and the Coefficient of Variation (CV). The study found no significant seasonal concentration in tourism in Macedonia, a presence of strong and powerful seasonality for Ohrid, and no seasonality for Skopje. As a consequence, the paper recommends design of specific tailor-made products and urges tourism key players to focus on policies and strategies for modifying tourism seasonality.
\end{abstract}

Keywords: Seasonality, tourism demand, entrepreneurship, tourism policy

\section{INTRODUCTION}

$\mathrm{D}$ espite the fact that seasonality is general characteristic of tourism, it is often detected as one of its most undesired companions due to profound negative effects that produces. Being identified as a tendency that is related to concentration of tourism flows in a particular time-segment, seasonality is closely related to tourism development. On the other side, tourism can promote and cause long-term economic growth, known as tourism-led growth hypothesis [1]. Furthermore, it urges the planning decisions in tourism as an issue of great challenge for each national government [2] since they view tourism as a catalyst for economic growth, meaning active participation in tourism industry [3]. Due to fact that tourism is generated by demand, the possibility arises that tourism demand may assist in providing in-depth analysis about tourist flows. This is of great assistance in decision-making process and drawing up tourism policies [4]. Therefore, it is widely recognized the need of investigating and clarifying the nature of seasonality in the line of identifying appropriate tourism policy and strategy.

Regardless the level of economic development, each country is interested in tourism due to its various positive impacts. Generally, tourism contributes to economic growth and development, promoting international understanding and peace, improving living standard, stimulating local trade and industry development, protection of cultural heritage etc. [5]. In this line, seasonality is noted as one of the most influencing factors for limiting continuous development. So, one may understand it as a phenomenon that provokes incomplete and unbalanced usage of means necessary for economic development [6]. Seasonality in tourism may be measured in various ways, but the most common approach is by estimating seasonal factors in time series, using pro-

Faculty of Tourism and Business Logistics, Goce Delcev University - Stip,

Krste Misirkov bb, 2000 Stip, Macedonia

2 Faculty of Tourism and Hospitality - Ohrid, University of St. Clement Ohridski - Bitola,

Kej Makedonija 95, 6000 Ohrid, Macedonia 
portional deviates to moving averages, through dummy variables in multiple linear regression [7] or by application of more advanced econometric models [8] - [10].

This paper attempts to empirically test and compare the presence of seasonal patterns in tourism development at national and local level. Moreover, the intention is to conclude whether to identify the same policy and strategy for tourism development at national and local level, or there is a necessity to develop diversified tourism product due to (un)presence of temporal imbalance in tourism flows. In this line, the main dilemma is having constant seasonal tourism concentration or just a high tourism demand. Hence, the aim is three-folded: First, to gain an in-depth knowledge regarding the (un)presence of seasonal tourism spreads; Second, to empirically test and analyze the strength and dynamics of tourism seasonality; and Third, to address adequate business strategies/policies which may significantly improve seasonality.

Although this paper adds to the current literature on tourism seasonality, its main contribution lies in its highlighting to suggest business strategies and policies which may significantly decrease negative seasonal effects. Investigating and assessing seasonal patterns in tourism in Macedonia from this perspective has thus far been limited. Some studies are noted, but in addressing seasonality effects at national level of Macedonia [11] - [13]. So, the current work pays no attention to such comprehensive approach like this paper explores, whereas an attempt is made to quantify seasonality patterns at local level, which represents a novelty in Macedonia's academic work. The paper has a practical significance since recommends design and development of specific tailor-made products that may overcome seasonality particularly in summer tourist centers, which may lead to more balanced distribution of tourism demand. The study praises that tourism key players at national and local level should focus on policies and strategies in the line of modifying tourism seasonality patterns.

In order to meet the aims, the paper is structured in several parts. After the introductory part, the following section gives a brief overview on theoretical aspects of the main reasons for seasonality in tourism flows, underlining the most profound negative, as well as positive effects. A snapshot on stylized facts on tourism flows of Macedonia, Ohrid (as the most famous summer tourist spot and a "must-see" destination in the country) and Skopje (the capital) is given in the forthcoming section. Section three encompasses the study's methodology, and section four presents the main findings and discussion. The article's final sections offer conclusions and recommendations, as well as limitations of the current study and future work.

\section{LITERATURE REVIEW}

The subject of seasonality in tourism is highly explored by elaborating its negative and positive effects. Generally, the academia agrees that seasonality occurs due to temporary imbalance in tourism flows caused by different determinants [14] - [25].

Among variety of factors that provoke seasonality in tourism demand one may note:

- Natural element (sunny days, snow falls, insolation, rainfall etc.). Tourists have specific preferences which make it necessary to distinguish between different tourism types;

- Institutional factor (religious and pilgrimage travel, workers' holidays, students' ferries, festival events etc.); and

- Other factors (social pressure, personal preferences, inertness etc.). 
Furthermore, it is noted that seasonality as systematic variation may be present not only during the year or a semester, but also in the frames of a month or a week, even in a single day [26] [27]. In this line, it is generally recognized that seasonality tends to have much more negative effects on tourism development, which often cannot be controlled [28] - [32]. In this respect, the negative impacts are addressing: Employment (part-time employment, social instability and insecurity etc.); Investments (high risks over law occupancy rate); and Environment (pollution, overcrowding, xenophobia, criminal activity etc.). Yet, they may be treated with an extension of the season by introducing new tourist products immune to seasonality; application of positive pricing policy; developing business tourism, etc. [33] - [35].

Besides the long list of negative impacts of seasonal patterns on tourism development, there is a literature that supports the approach that seasonality provokes positive effects as well. This is particularly in terms of sociology and ecology. Namely, after devastating high season, long and quiet period is more than welcomed especially for recovering the sources, and the local population as well [18], [36] - [38].

\section{SEASONALITY OR JUST A HIGH TOURISM DEMAND? NATIONAL VS. LOCAL}

This section poses brief introduction on some general facts referring tourism demand. The main idea is to present data on tourism flows upon which, to assess and compare the presence of seasonality in tourism development at different levels. In this line, the data for Macedonia refer to the central level, and on the other hand, the data for local level stand for Ohrid and Skopje.

\begin{tabular}{|c|r|r|r|r|r|r|r|r|r|}
\cline { 2 - 12 } \multicolumn{1}{c|}{} & \multicolumn{3}{|c|}{ Domestic } & \multicolumn{3}{c|}{ Foreign } & \multicolumn{3}{c|}{ Total } \\
\hline Year & \multicolumn{1}{c|}{ MKD } & \multicolumn{1}{c|}{ Ohrid } & \multicolumn{1}{c|}{ Skopje } & \multicolumn{1}{c|}{ MKD } & \multicolumn{1}{c|}{ Ohrid } & \multicolumn{1}{c|}{ Skopje } & \multicolumn{1}{c|}{ MKD } & \multicolumn{1}{c|}{ Ohrid } & \multicolumn{1}{c|}{ Skopje } \\
\hline 2000 & 408,507 & 153,510 & 24,659 & 22,4016 & 56,318 & 66,508 & 632,523 & 209,828 & 91,167 \\
\hline 2001 & 234,362 & 86,258 & 17,101 & 98,946 & 11,499 & 46,061 & 333,308 & 97,757 & 63,162 \\
\hline 2002 & 318,851 & 137,911 & 15,712 & 122,861 & 25,517 & 54,008 & 441,712 & 163,428 & 69,720 \\
\hline 2003 & 325,459 & 136,420 & 21,115 & 157,692 & 39,390 & 61,627 & 483,151 & 175,810 & 82,742 \\
\hline 2004 & 299,709 & 114,652 & 19,386 & 165,306 & 37,522 & 64,417 & 465,015 & 152,174 & 83,803 \\
\hline 2005 & 312,490 & 116,401 & 23,302 & 197,216 & 49,564 & 70,850 & 509,706 & 165,965 & 94,152 \\
\hline 2006 & 297,116 & 114,754 & 20,244 & 202,897 & 52,640 & 71,522 & 499,473 & 167,394 & 91,766 \\
\hline 2007 & 306,132 & 123,854 & 20,314 & 230,080 & 57,456 & 79,396 & 536,212 & 181,310 & 99,710 \\
\hline 2008 & 350,363 & 139,643 & 16,036 & 254,957 & 62,461 & 96,674 & 605,320 & 202,104 & 112,710 \\
\hline 2009 & 328,566 & 122,258 & 14,823 & 259,204 & 67,441 & 90,520 & 587,770 & 189,699 & 105,343 \\
\hline 2010 & 324,545 & 105,213 & 12,784 & 261,696 & 59,896 & 91,288 & 586,241 & 165,109 & 104,072 \\
\hline 2011 & 320,097 & 102,730 & 12,740 & 327,471 & 75,547 & 105,170 & 647,568 & 178,277 & 117,910 \\
\hline 2012 & 312,274 & 99,850 & 15,284 & 351,359 & 83,485 & 113,928 & 663,633 & 183,335 & 128,312 \\
\hline 2013 & 302,114 & 91,395 & 16,475 & 399,680 & 100,109 & 128,968 & 701,794 & 191,504 & 145,443 \\
\hline 2014 & 310,336 & 88,118 & 15,834 & 425,314 & 109,078 & 140,540 & 735,650 & 197,196 & 156,374 \\
\hline 2015 & 330,537 & 94,476 & 19,187 & 485,530 & 125,468 & 173,014 & 816,067 & 219,944 & 192,201 \\
\hline 2016 & 346,359 & 107,351 & 18,534 & 510,484 & 127,010 & 183,613 & 856,843 & 234,361 & 202,147 \\
\hline Average & 319,283 & 113,811 & 17,855 & 274,983 & 67,082 & 96,359 & 594,530 & 180,894 & 114,161 \\
\hline
\end{tabular}

Table 1: Tourist arrivals in Macedonia, Ohrid and Skopje, 2000-2016

Source: State Statistical Office (various years, various publications) [39]

Table 1 presents data on tourist arrivals (domestic, foreign and total) in Macedonia, Ohrid and Skopje, for the period 2000-2016. With exception of 2001 (war conflict in Macedonia) and stag- 
nation in 2010 (World economic crisis), one may note an upward trend in all case studies. The average total number of tourists for the sample period for Macedonia is 594,234 tourists, for Ohrid is 180,894 and for Skopje 114,161 tourists. This means that Ohrid represents an average share of $30.4 \%$ and Skopje $19.2 \%$.

Speaking of Ohrid, one may emphasize that it is the most famous tourist destination in Macedonia that generally develops summer tourism simultaneously with other forms of alternative tourism (cultural, congress, etc.). Based on Table 1, it is noticeable that up to 2008, domestic tourists are by far dominant over the foreigners by encompassing up to $69 \%$ of total tourist arrivals that visited Ohrid. When comparing to the arrivals of domestic tourists in Macedonia, it contributes with an average share of $40 \%$. Yet, due to the governmental measures and activities for supporting and enhancing tourism development by introducing subsidies, the proportion changed in favor to foreign tourists. Namely, a rapid decline of domestic tourists that visited Ohrid is noticeable as of 2009 to 2015, leading to 'only' 28\% participation of domestic in total tourist arrivals. Consequently, in 2013 foreign tourists overtook the leading role for the first time in tourism development of Ohrid by covering $52 \%$ of total number of tourists that visited this destination. This represents an average share of $23.9 \%$ of Ohrid's foreign tourists in the frames of foreign tourists that visited Macedonia. However, besides the increased number of foreigners towards domestic tourists, the average absolute numbers for 2000-2016, still illustrate dominancy of domestic tourists on national level (53.7\%) and for Ohrid 62.9\%, with 319,283 (Macedonia), and 113,811 (Ohrid) arrivals towards 274,983 and 67,082 respectively arrivals of foreign tourists. On the other side, this is not the case for Skopje, whereas foreign tourists are by far dominant with $84.4 \%$ of total arrivals. Even more, Skopje in average has 1.4 times more foreign tourists than Ohrid, representing one-third of the average arrivals in Macedonia. As of 2000, the number of foreign tourists that visited Skopje has almost tripled, generally due to favorable conditions in terms of new city tourism product, new direct charter flights to Skopje airport, subsidies for incoming travel agencies, etc.

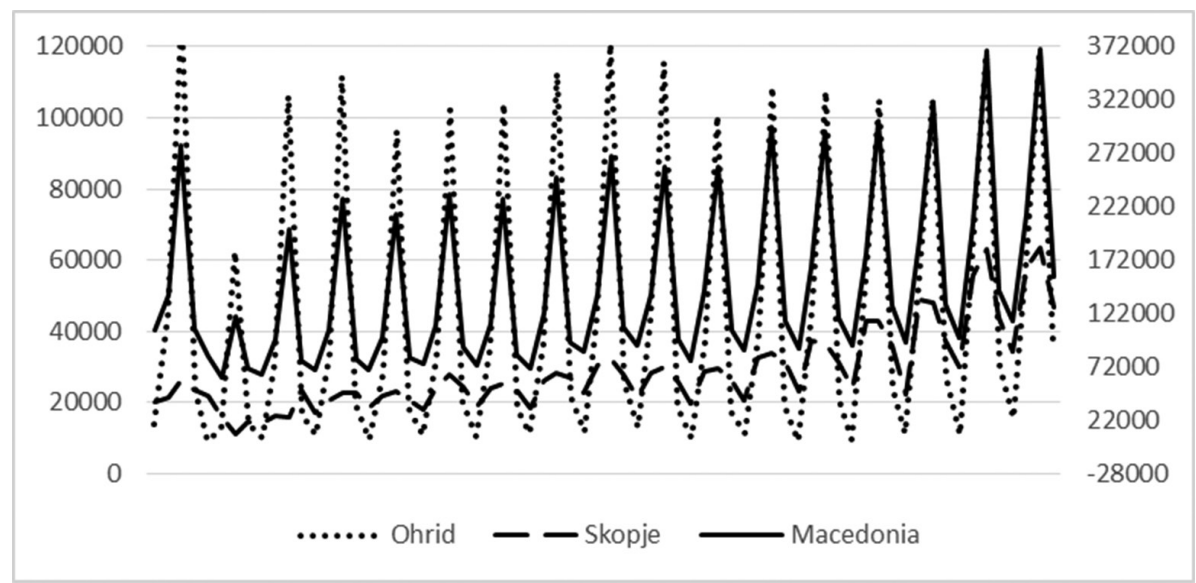

Figure 1: Distribution of tourism flows for Macedonia, Ohrid and Skopje, 2000-2016 Source: State Statistical Office (various years, various publications) [39]

Figure 1 visually presents monthly distribution of tourism flows in Macedonia, Ohrid and Skopje in terms of tourist arrivals for the period 2000-2016. One may clearly note similarities in the distribution among Macedonia and Ohrid, whereas the third quarter (composed of summer months July, August and September), undoubtedly encompasses the largest quantum of tourists and travelers, thus representing the highest peak-point i.e. the highest tourism demand. Moreover, in the case of Macedonia this quarter covers $45 \%$ and in the case of Ohrid covers $61 \%$ of total average tourism demand. Therefore, the general conclusion for the entire sample period is that the third quarter 
performs highest results when referring tourist arrivals. On the other side, this cannot be concluded for the case of Skopje. Namely, as of Figure 1 it can be seen that the second and third quarter have very similar distribution of tourism flows. Moreover, in average the third quarter encompasses only $5.5 \%$ of total average tourism demand. This may be supported with the fact that Skopje as the capital, attracts various types of visitors, which generally are not driven by weather conditions. Moreover, in the cases of Macedonia and Ohrid, summer months have extremely high performances even in 2001, which is the weakest year in tourism manner due to the war conflict. The absolute dominance of these months may be explained with presence of multiple factors. Namely, in these months the usage of holidays and ferries is the highest (institutional factor), there is hot and sunny weather (particularly for the lake resort Ohrid) (natural factor) and there is a manifestation of personal preferences and attitudes of tourists and travelers (other factors). The fact that Ohrid is a summer tourist destination explains the high average numbers for July (28\%) and August (27\%). Consequently, at first glance this may seem as a strong seasonality pattern, being additionally confirmed by an in-depth analysis, which is not the case with Macedonia. Namely, at national level, July participated in average with only $18.4 \%$ and August with $18.6 \%$ representing 2.5 times smaller concentration compared to the local case of Ohrid. In the case of Skopje, the figures are completely opposite. The highest peak is noted in September (an average of $10.4 \%$ ), followed by October and May. The first visual conclusion of having seasonality or just high tourism demand with no significant seasonal patterns, is additionally empirically confirmed.

\section{METHODOLOGY}

The analysis is made upon a computation of several commonly applied statistical measures for which an annual single measure of the seasonality's extend is calculated. This is done to the purpose of providing information about whether counter-seasonal policies need to be introduced and to which level. The paper analyses the seasonal concentration of tourism demand at national and local level by calculating the Gini index (G), the Seasonality Indicator (SI) and the Coefficient of Variation (CV). The main variable is the total number of tourists on monthly basis for Macedonia, Ohrid and Skopje, during the period 2000-2016.

The Gini index is one of the most commonly used coefficients for measuring inequality of revenues caused by temporary disorders. It is widely applied for measuring dispersion and concentration in tourism [40] - [48], [7], [33] - [34], [25]. In this line, different approaches are noted for calculating the Gini index [49]. In a monthly series, the Gini index of an annual set of observations ranges from 0 (perfect equality between months) to 1 (perfect inequality between months). The G may be 0 only in the case when all 12 data are the same, pointing to egalitarian distribution over the whole year. To the opposite, the maximum value of $\mathrm{G}$ to be 1 may be reached only in a case when 11 data are 0 and only one data (month) has a non-null value. Consequently, the higher $\mathrm{G}$ represents greater inequality i.e. degree of seasonal concentration in tourism, and vice versa. Herein, the Gini index is calculated upon standard equation (Eq. 1).

$$
\mathrm{G}=2 / \mathrm{n} \Sigma \mathrm{ni}=1(\mathrm{xi}-\mathrm{yi})=2 / \mathrm{n}[(\mathrm{x} 1-\mathrm{y} 1)+(\mathrm{x} 2-\mathrm{y} 2)+\ldots+((\mathrm{xn}-\mathrm{yn})]=2 / \mathrm{n}[\Sigma \mathrm{ni}=1 \mathrm{xi}-\Sigma \mathrm{ni}=1 \mathrm{yi}]
$$

Whereas:

$\mathrm{n}$ denotes number of months;

xi denotes rank of the months $(1 / 12,2 / 12, \ldots, 12 / 12)$; and

yi denotes cumulative relative frequency of tourist arrivals in rank by ascending order. 
The Seasonal Indicator is commonly used measure for quantifying empirically observed seasonality patterns in tourism. It can be calculated as an inverse value of the seasonality ratio [50], [25]. The value ranges from 1/12 up to 1 . In case of having bigger values, it means that there is an absence of fluctuation during the year, i.e. seasonality in tourism, and opposite. The SI may be calculated upon standard equation (Eq. 2).

$$
\mathrm{SI}=\frac{y_{0}}{y_{n}}
$$

Whereas:

$\mathrm{y}_{0}$ denotes the average number of tourist arrivals per year; and

$\mathrm{y}_{\mathrm{n}}$ denotes the highest number of tourist arrivals in the particular year.

The Coefficient of Variation describes the fluctuation of tourists during the year. Moreover, it measures the spread of each series around its annual mean as a percentage of that mean. This indicator is particularly useful for comparing dispersion in data sets having different standard deviations and different means. It can take values beginning with zero. If the value is small, then the distribution is much homogenous and the average is much more representative. Yet, despite the simplification in calculating it, it may be difficult to interpret the results appropriately [51], [36], [23], [25]. The CV may be calculated as a ratio between the standard deviation and the distribution average [52] (Eq. 3).

$$
\mathrm{CV}=\frac{s}{y_{0}}
$$

Whereas:

$\mathrm{s}$ denotes the standard deviation; and

$\mathrm{y}_{\mathrm{o}}$ denotes the mean of the observations in the particular year.

\section{ANALYSIS, RESULTS AND DISCUSSION}

The data referring seasonality of tourism demand at national and local level are presented in Table 2. It is interesting that conclusion differs when testing presence of seasonality at national level, and two case studies at local level.

The first calculated indicator for testing the presence of seasonality is the Gini index. In the case of Macedonia, this coefficient spreads between 0.2042 and 0.3074 , with an average value for the sampled period of 0.2801 . Moreover, all calculated values of $\mathrm{G}$ are similar, almost identical and approximately constant with small negligible variations ( $G$ has the lowest value in 2001 due to the war conflict). The data show that seasonality in terms of intra-year monthly variations in tourist arrivals is constant during the 17-year period. Due to fact that calculations referring Gini index are far below the margin of 0.5 , one may conclude presence of very modest seasonality. Namely, the low value of $\mathrm{G}$ shows that current distribution of tourism demand for the sample period has no meaning to Macedonia. Therefore, the concentration in terms of tourist arrivals at national level points to relative balance and equality. Thus, high peaks in July and August have not sufficient capacity and strength for serious influence with an in-depth manner. The second calculated indicator is the Seasonality Indicator. It was found that the calculated values range between 0.3960 and 0.4828 noting an average value of 0.4340 . Since all computed data are far above zero, one may argue humble fluctuation within a year pointing to fragile tourism concentration at national level. 
The final indicator is the Coefficient of Variation being used numerically to measure stability of tourism demand distribution. In the case of Macedonia, it spreads between $42.5 \%$ and $69.2 \%$ with an average of $59.8 \%$. The values are above the limit of $35-40 \%$ pointing to non-homogeneous distribution and conclusion is that the average is no more representative.

\begin{tabular}{|c|r|r|r|r|r|r|r|r|r|}
\cline { 2 - 11 } \multicolumn{1}{c|}{} & \multicolumn{3}{c|}{ G } & \multicolumn{3}{c|}{ SI } & \multicolumn{3}{|c|}{ CV (\%) } \\
\hline Year & \multicolumn{1}{c|}{ MKD } & Ohrid & \multicolumn{1}{c|}{ Skopje } & \multicolumn{1}{c|}{ MKD } & \multicolumn{1}{c|}{ Ohrid } & \multicolumn{1}{c|}{ Skopje } & MKD & Ohrid & Skopje \\
\hline 2000 & 0.2626 & 0.4958 & 0.0711 & 0.4385 & 0.2973 & 0.8007 & 58.2 & 110.9 & 13.3 \\
\hline 2001 & 0.2042 & 0.5003 & 0.1468 & 0.4828 & 0.2419 & 0.6523 & 42.5 & 124.5 & 27.3 \\
\hline 2002 & 0.2931 & 0.5419 & 0.1169 & 0.3960 & 0.2557 & 0.6399 & 67.0 & 125.9 & 24.1 \\
\hline 2003 & 0.3074 & 0.5126 & 0.0803 & 0.4103 & 0.2815 & 0.8188 & 69.2 & 118.3 & 14.9 \\
\hline 2004 & 0.2878 & 0.5101 & 0.0803 & 0.4129 & 0.2754 & 0.7566 & 64.7 & 117.9 & 15.7 \\
\hline 2005 & 0.2802 & 0.4926 & 0.1101 & 0.4187 & 0.2748 & 0.7102 & 63.6 & 112.9 & 21.4 \\
\hline 2006 & 0.2825 & 0.5014 & 0.0843 & 0.4257 & 0.2862 & 0.8183 & 63.0 & 112.5 & 15.5 \\
\hline 2007 & 0.2993 & 0.5026 & 0.0968 & 0.4104 & 0.2780 & 0.8240 & 65.3 & 114.1 & 18.5 \\
\hline 2008 & 0.2834 & 0.4958 & 0.0916 & 0.4325 & 0.3115 & 0.7864 & 61.1 & 108.0 & 17.1 \\
\hline 2009 & 0.2759 & 0.4997 & 0.0942 & 0.4419 & 0.3037 & 0.8010 & 59.3 & 109.9 & 17.5 \\
\hline 2010 & 0.2806 & 0.4888 & 0.1083 & 0.4470 & 0.3117 & 0.8238 & 59.1 & 107.0 & 20.3 \\
\hline 2011 & 0.2849 & 0.4892 & 0.1390 & 0.4506 & 0.3094 & 0.7346 & 60.1 & 104.3 & 25.5 \\
\hline 2012 & 0.2783 & 0.4841 & 0.1404 & 0.4730 & 0.3380 & 0.7580 & 56.3 & 98.3 & 26.1 \\
\hline 2013 & 0.2795 & 0.4747 & 0.1481 & 0.4583 & 0.3501 & 0.7500 & 55.6 & 93.1 & 27.4 \\
\hline 2014 & 0.2915 & 0.4454 & 0.1894 & 0.4215 & 0.3701 & 0.6608 & 58.1 & 86.5 & 34.8 \\
\hline 2015 & 0.2989 & 0.4446 & 0.1724 & 0.4028 & 0.3594 & 0.7004 & 60.5 & 86.0 & 31.6 \\
\hline 2016 & 0.2716 & 0.4015 & 0.1550 & 0.4555 & 0.4129 & 0.7149 & 53.7 & 77.0 & 28.4 \\
\hline Average & 0.2801 & 0.4871 & 0.1191 & 0.4340 & 0.3093 & 0.7501 & 59.8 & 106.3 & 22.3 \\
\hline
\end{tabular}

Table 2: Summarized seasonality data for Macedonia, Ohrid and Skopje, 2000-2016 Source: Authors' calculations

When elaborating the first local case of Ohrid, it is calculated that $\mathrm{G}$ index spreads between 0.4015 and 0.5419 , with an average value of 0.4871 . It is noticeable that the calculations referring Gini index are similar, almost identical and approximately constant with small negligible variations, being very close to the margin of 0.5 , which implies presence of high seasonality. Furthermore, the high values of $\mathrm{G}$ show that current distribution of tourism demand has substantial meaning to Ohrid. Hence, the concentration in terms of tourist arrivals in Ohrid points to significant unbalance and large inequality i.e. high tourism seasonality with significant characteristics. Thus, the high peaks in the third quarter, particularly in July and August have sufficient capacity and strength for serious influence with an in-depth manner. With regards to the calculated values for SI for Ohrid, they range between 0.2419 and 0.4129 , noting an average value of 0.3093 . The computed data are relatively close to zero, and by far lower compared to the case of Macedonia and Skopje, indicating strong fluctuation within a year and presence of resilient tourism seasonality at local level. Finally, the calculated values for CV spread between $77 \%$ and $125.9 \%$, with an average of $106.3 \%$, being above the critical values.

The investigation of the case of Skopje revealed that computed G values are between 0.0711 and 0.1894 (an average of 0.1191 ) being extremely far from the critical value of 0.5 pointing to complete absence of seasonality patterns. The computed values for SI are between 0.6399 and 0.8240 (an average of 0.7501 ) being very far above zero, pointing once again to no seasonality. Finally, the calculations for CV present that data spread between $13.3 \%$ and $34.8 \%$, being within the critical interval, and pointing to relatively balanced distribution. 
Figure 2 presents the graphical representation of the computed $G$ values by presenting the average Lorenz curves of Macedonia, Ohrid and Skopje. It is noticeable that the area between the average Lorenz curve of Skopje and the Line of equity is the smallest, compared to other two curves. This points to equal seasonal distribution of tourist arrivals and absence of seasonal concentration when addressing the local case of Skopje. Herein, it is confirmed that Skopje as tourist destination, has constant, similar and low values of the $\mathrm{G}$ index pointing to no seasonality.

On the other hand, the area between the average Lorenz curve of Macedonia and the Line of equality is relatively small, not like in the case of Skopje, but rather smaller compared to the case of Ohrid. This points to relatively equal seasonal distribution of tourist arrivals and no meaningful seasonal concentration at national level. At the same time, Figure 2 confirms the conclusion previously discussed for the local case of Ohrid. Namely, one may note that the area between the average Lorenz curve of Ohrid and the Line of equity is big, thus pointing to unequal seasonal distribution of tourist arrivals and presence of strong and powerful seasonality.

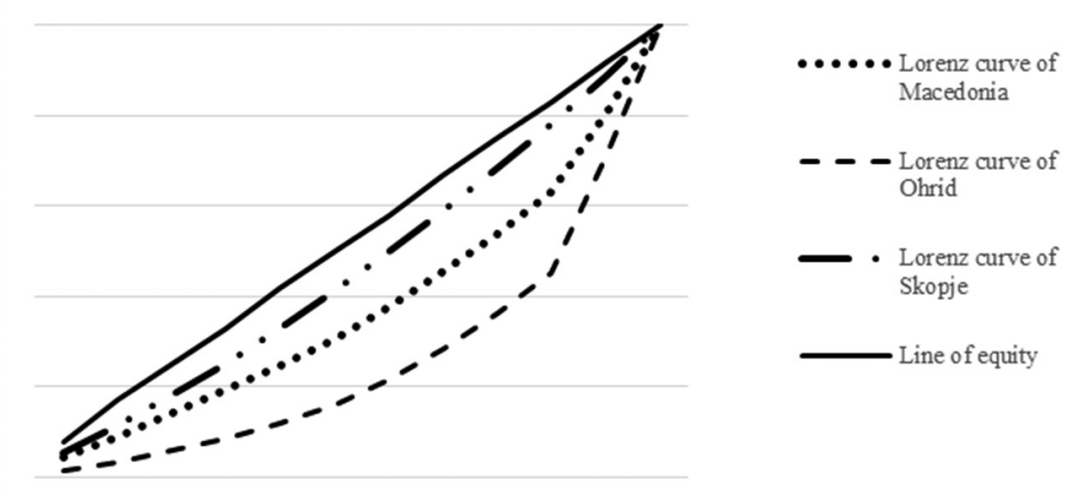

Figure 2: Average Lorenz curves of Macedonia, Ohrid and Skopje, 2000-2016 Source: Authors' calculations

\section{ENTREPRENEURIAL STRATEGIES FOR SEASONALITY SPREADS}

Seasonality is stable, well-established pattern, with some elements of predictability. This helps managers to anticipate seasonality impacts and implement counter strategies to minimize potential negative effects. Infrastructure development can accelerate off-season visits. Travel between Skopje and Ohrid may be shortened to 1.5 hours driving, as a result of the development of current highway construction projects, namely, Kicevo - Trebenishte - Ohrid - Struga - Kafasan border crossing with Albania, and upcoming construction project of Gostivar - Kicevo highway development. Infrastructure expansion may improve destination accessibility, thus enabling alleviating the problem of seasonality by shortened travel and off-season visits availability. There is a need for additional activities in tourism destinations during the off-season, which may influence product diversification [53]. New innovative products (culture and heritage-based products) are less weather sensitive, especially during the off-season. Here can be included specialized holidays tailored to various market segments in line with their special interests, such as, motor boating which is attractive activity not only during the off-season, but also during the peak season. Furthermore, marketing campaigns via internet and other media highlight destination uniqueness and underline different travel markets. Adequate promotion transforms destinations into distinctive places and improves destination performance during the off-season. 
Various visitor management tools [54] should be developed to address environmental issues due to overcrowding during the peak season. The visitors should be required to respect the environment [55] through rules implementation which will restrict certain behavior of tourists. Ecological footprints of tourists should be kept at minimum.

Another issue in managing tourism demand is price discounts [56]. Price discounts do not necessarily improve off-season visitation, but opposite, may have negative destination imagery, due to tourists' judgement sense about the value for money. Instead, service differentiation is a better tool in addressing the seasonality throughout the seasons. Another issue is addressing seasonality in family businesses [57]. Normally, a family firm is trying to cope with seasonality by coping, combating or capitulating. The most useful strategy variations are forming around the product, and market diversification, price differentials and government-initiated measures. Developing events and festivals besides above ones, also assists as a counter seasonality initiative.

The main markets for off-season tourism are business travelers, youth, senior citizens, special-interest tourists, and certain socio-economic niche markets. The businesses and destinations should select appropriate strategy based on the causes and their seasonal impacts. For example, market segmentation can result in a niche product which will increase tourist flow during the low periods. Causes of seasonality are different for each location. Managers and travel agents are addressing these causes with appropriate strategy development. Government initiatives can expand temporal distribution of tourism, geographically and during the low periods.

\section{CONCLUSION}

By using some of the most applied indicators (Gini index, SI and CV), the paper investigates the seasonal concentration of tourism demand in terms of total tourism arrivals at national level, and two case studies at local level. At the same time, the paper underlines the importance of seasonality as one of the major and profound limits generally for utilization of tourism infrastructure and effects on region's economy and employment. Concerning the national level, it was found a presence of seasonality with no meaningful patterns. Hence, the empirical tests point to no significant seasonal concentration in tourism in Macedonia, but rather presence of modest tourism development in the country.

Besides national level, the paper investigated the seasonality effects over local tourism development, by elaborating the case of Ohrid, as the most famous summer tourist spot and a "mustsee" destination, and the case of Skopje - the capital. The computed values pointed to completely opposite findings. For Ohrid was found strong and very powerful seasonality, while for Skopje, equal distribution of tourism flows and no seasonality. Moreover, the analysis posed that for Ohrid, in the third quarter exist cumulative influence of many factors that provoke extended concentration and increased tourism demand, like: favorable weather conditions; extensive insolate days; usage of vacations and ferries; personal preferences for summer season etc. So, the researched revealed strong and robust seasonality patterns only for Ohrid, where the distribution i.e. concentration of tourism demand was found to be substantial with considerable meaning to the local and regional tourism development.

The strong effects of tourism seasonality can be managed, mitigated and controlled, but cannot be avoided. Despite numerous attempts to overcome seasonality, still plenty needs to be done, such as: lengthening the main season, establishing additional seasons, diversifying markets, using differential pricing and tax incentives on a temporal basis, encouraging the staggering 
of holidays, boosting domestic tourism in off-seasons, and providing off-season attractions or events. In addition, special events such as festivals and conferences may help to overcome the seasonal effects, if they take place in the shoulder or off-season. Yet, tourists expect to have attractive programs organized during the main season and out of it. So generally, in order to address the negative effects of seasonality, tourism policy makers of Ohrid may argue introducing different strategies in the line of supporting further local tourism development, mainly:

- Differential pricing (seasonal/promotional pricing; group booking offers etc.);

- Diversified attraction (changing the product mix);

- Market diversification (determination of optimal segment mix);

- Facilitation by the state and local players (loans or subsidies; tax concession; legislative initiatives; partnerships etc.).

\section{LIMITATIONS AND FUTURE WORK}

The analysis was limited by several factors that can also serve as productive starting points for future work.

First, the sample period (2000-2016) is rather short due to publicly unavailable monthly data. In case of having longer time series, the conclusions on seasonality impacts on tourism development may have more serious meaning since it may reflect much extensive time-frame.

Secondly, the investigation uses relatively simple technique which all-the-way can be helpful in some contexts. Yet, the outcomes may be enhanced by employing more advanced methods, like: SARIMA (Seasonal Autoregressive Moving Average) models, TQSAR (Two-Quarter Smoothed Annualized Rate) method, HP (Hodrick-Prescott) filter smoothing method, BSM (Basic Structural Model), HEGY test etc.

Finally, instead of using one technique, future research may employ multiple models and theories relevant to the assessment of tourism seasonality.

Notwithstanding the difficulties involved with assessing the presence of seasonal patterns in tourism at national and local level, this article assists better to understand fluctuations of tourism data in order better to handle tourism demand planning. 


\section{REFERENCES}

[1] Brida, G. H., Barquet, A., Risso, A. W. (2010) Causality between economic growth and tourism expansion: empirical evidence from Trentino-Alto Adige, Tourismos: An International Multidisciplinary Journal of Tourism, Vol. 5 Np. 2, pp. 87-98.

[2] Brida, G. H., Osti, L., Santifaller, E. (2011) Second homes and the needs for policy planning, Tourismos: An International Multidisciplinary Journal of Tourism, Vol.6 No. 1, pp. 141163.

[3] Cheang, V. (2009) State and tourism planning: a case study of Cambodia, Tourismos: An International Multidisciplinary Journal of Tourism, Vol.4 No. 1, pp. 63-82.

[4] Claveria, O., Datzira, J. (2009) Tourism demand in Catalonia: detecting external economic factors, Tourismos: An International Multidisciplinary Journal of Tourism, Vol. 4 No. 1, pp. 13-28.

[5] Goeldner, C., Ritchie, B., McIntosh, R. (2000) Tourism: Principles, Practices, Philosophies, John Wiley \& Sons.

[6] BarOn, R. R. V. (1973) Seasonality in tourism - part II, International Tourism Quarterly, Vol. 1, pp. 51-67.

[7] Fernández-Moralez, A. (2003) Decomposing seasonal concentration, Annals of Tourism Research, Vol. 30 No, 4, pp. 942-956.

[8] Ashworth, J., Thomas, B. (1999) Patterns of Seasonality in Employment in Tourism in the UK, Applied Economics Letters, Vol. 6, pp. 735-739.

[9] González, P., P. Mora, P. (1996) Analysis of Tourism Trends in Spain, Annals of Tourism Research, Vol. 23, pp. 739-754.

[10] Sorensen, N. (1999) Modelling the Seasonality of the Hotel Nights in Denmark by Country and Nationality, Tourism Economics, Vol. 5, pp. 9-23.

[11] Petrevska, B. (2013) Investigating tourism seasonality in Macedonia, UTMS Journal of Economics, Vol. 4 No. 1, 37-44.

[12] Petrevska, B. (2013) A simple test for the presence of seasonality in tourism in Macedonia, Conference Proceedings from the $1^{\text {st }}$ International Conference "Regional Economic Cooperation in the process of Globalization", 6-7 Dec 2013, Tetovo, Macedonia.

[13] Petrevska, B. (2013) Empirical analysis of seasonality patterns in tourism, Journal of Process Management - New Technologies International, Vol. 1 No. 2, pp. 87-95.

[14] BarOn, R. R. V. (1993) Seasonality. In: Khan, M. A., Olsen M. D., and Var, T.(eds), VNR's Encyclopedia of Hospitality and Tourism. New York: Van Nostrand Reinhold.

[15] BarOn, R. R. V. (1999) The measurement of seasonality and its economic impacts, Tourism Economics, Vol. 5 No. 4, pp. 437-458.

[16] Baum, T. (1999) Seasonality in tourism: understanding the challenges, Tourism Economics, Vol. 5 Np. 1, pp. 5-8.

[17] Baum, T., Lundtorp, S. (2001) Seasonality in Tourism. Amsterdam.

[18] Butler, R. (1994) Seasonality in tourism: issues and problems. In Seaton, A. V.(ed.), Tourism: The state of the Art. John Wiley \& Sons Ltd, pp. 332-339.

[19] Chung, J. Y. (2009) Seasonality in tourism: a review, e-Review of tourism research, Vol. 7 No. 5, pp. 82-96.

[20] Higham, J., Hinch, T. (2002) Tourism, sport and seasons: the challenges and potential of overcoming seasonality in the sport and tourism sectors, Tourism Management, Vol. 23, pp. 175-185.

[21] Jang, S. (2004) Mitigating tourism seasonality: a quantitative approach, Annals of Tourism Research, Vol. 31 No. 4, pp. 819-836. 
[22] Koenig, N., Bischoff, E. E. (2004) Analyzing seasonality in Welsh room occupancy data, Annals of Tourism Research, Vol. 31 No. 2, pp. 374-392.

[23] Lundtorp, S. (2001) Measuring Tourism Seasonality. In: Baum, T. and Lundtorp, S.(eds), Seasonality in Tourism. London; Amsterdam: Pergamon.

[24] Rodrigues, P. M. M., Gouveia, P. M. D. (2004) An application of PAR models for tourism forecasting, Tourism Economics, Vol. 10, pp. 281-303.

[25] Yacoumis, J. (1980) Tackling seasonality: the case of Sri Lanka, Tourism Management, Vol. 1 No. 2, pp. 84-98.

[26] Holloway, C. J. (1994) The hospitality sector: accommodation and catering services. London: Pitman Publishing.

[27] Lundberg, D. E., Krishamoorthy, M., Stavenga, M. H. (1995) Tourism economics. John Wiley and Sons Inc.

[28] Allcock, J. B. (1989) Seasonality. In: Witt, S. F. and Moutinho, L. (eds). Tourism Marketing and Management Handbook. London: Prentice Hall, pp. 387-392.

[29] Edgell, D. L. (1990) International tourism policy. New York: Van Nostrand Reinhold.

[30] Laws, E. (1991) Tourism marketing: service and quality management perspectives. Stanley Thornes Publishers.

[31] Snepenger, D., Houser, B., Snepenger, M. (1990) Seasonality of demand, Annals of Tourism Research, Vol. 17, pp. 628-630.

[32] Szivas, E., Riley, M., Airey, D. (2003) Labor mobility into tourism: attraction and satisfaction, Annals of Tourism Research, Vol. 30 No. 1, pp. 64-76.

[33] Nadal, J. R., Font, A. R., Rossello, A. S. (2004) The economic determinants of seasonal patterns, Annals of Tourism Research, Vol. 31 No. 3, pp. 697-711.

[34] Sutcliffe, C. M. S., Sinclair, T. M. (1980) The measurement of seasonality within the tourist industry: an application of tourist arrivals in Spain, Applied Economics, Vol. 12 No. 4, pp. 429-441.

[35] Witt, S., Brooke, M. Z., Buckley, P. J. (1991) The management of international tourism, Unwin Hyman, London.

[36] Drakatos, G. C. (1987) Seasonal concentration of tourism in Greece, Annuals of Tourism Research, Vol. 14, pp. 582-586.

[37] Grant, M., Human, B., LePelley, B. (1997) Seasonality, Insights, Vol. 9 No. 1, pp. A5-A9.

[38] Hartmann, R. (1986) Tourism, seasonality and social change, Leisure Studies, Vol. 5 No. 1, pp. 25-33.

[39] State Statistical Office of the Republic of Macedonia. (various years). Various publications (Statistical Yearbooks), Skopje, Macedonia.

[40] Arnold, R. A. (2008) Economics, Cengage Learning, Mason.

[41] Bigovic, M. (2012) The strength and dynamics of the seasonal concentration in Montenegrin tourism, Turizam, Vol. 6 No. 3, pp. 102-112.

[42] Black, J. (2002) A dictionary of economics, Oxford University Press, New York.

[43] Fernández-Moralez, A., Mayorga-Toledano, M. C. (2008) Seasonal concentration of hotel demand in Costa del Sol: a decomposition by nationalities, Tourism Management, Vol. 29 No. 5, pp. 940-949.

[44] Grabler, K. (1997) Cities and the Destination Life Cycle. In: International City Tourism, K. Grabler, G. Maier, J. Mazanec and K. Wöber (Eds), pp. 54-71. London: Pinter.

[45] Lee, C. (1996) Input-output Analysis and Income Distribution Patterns in the Tourism Industry in South Korea, Asia Pacific Journal of Tourism Research, Vol. 1, pp. 35-49.

[46] Lee, C., Kang, S. (1998) Measuring Earnings Inequality and Median Earnings in the Tourism Industry, Tourism Management, Vol. 19, pp. 341-348. 
[47] Lim, C., McAleer, M. (2008) Analyzing seasonal changes in New Zealand's largest inbound market, Tourism Recreation Research, Vol. 33 No. 1, 83-91.

[48] Wöber, K. (1997) International City Tourism Flows, In International City Tourism, K. Grabler, G. Maier, J. Mazanec and K. Wöber, (Eds.), pp. 39-53. London: Pinter.

[49] Xu, K. (2003) How has the Literature on Gini's Index Evolved in the Past 80 Years? Halifax: Dalhousie University.

[50] Wanhill, S. R. C. (1980) Tackling seasonality: a technical note, International Journal of Tourism Management, Vol. 1 No. 4, pp. 243-245.

[51] Donatos, G., Zairis, P. (1991) Seasonality of foreign tourism in the Greek Island of Crete, Annals of Tourism Research, Vol. 18 No. 3, pp. 515-519.

[52] Roşca, E. (2009) The synthetical indicators of variability an approach in tourism, Annals of the ,SStefan cel Mare" University Suceava, Fascicle of The Faculty of Economics and Public Administration, Vol. 9, No. 1(9), 279-289.

[53] Benur, A. M., Bramwell, B. (2015) Tourism product development and product diversification in destinations, Tourism Management, Vol. 50, pp. 213-224.

[54] Candrea, A. N., Ispas, A. (2009) Visitor management, a tool for sustainable tourism development in protected areas, Bulletin of the Transylvania University of Brasov, Series V: Economic Sciences, Vol. 2 No. 51, pp. 131-136

[55] Jurdana, D. S., Zmijanović, L. (2014) The effect of tourism seasonality on protected areas, Tourism and Hospitality Industry 2014, Congress proceedings, Trends in Tourism and Hospitality Industry, pp. 131-146

[56] Forsyth, P., Dwyer, L. (2009) Tourism Price Competitiveness, The Travel \& Tourism Competitiveness Report.

[57] Bala Banki, M., Ismail, H. N., Muhammad, I. B. (2016) Coping with seasonality: A case study of family owned micro tourism businesses in Obudu Mountain Resort in Nigeria, Tourism Management Perspectives, Vol. 18, pp. 141-152. 